Int. J. Electrochem. Sci., 14 (2019) 9326 - 9336

\title{
Relationship between carrier density and corrosion behavior of acrylic polyurethane coated galvanized steel system in $3.5 \%$ NaCl solution
}

\author{
L. Lu*, T. L. Lu, M. Z. Ding, J. Gao
}

Corrosion and Protection Center, University of Science and Technology Beijing, Beijing100083, China *E-mail: 1ulin315@126.com

doi: $10.20964 / 2019.09 .68$

Received: 7 May 2019 / Accepted: 14 July 2019 / Published: 5 August 2019

Carrier density (CD) was adopted to investigate the corrosion process of acrylic polyurethane-coated galvanized steel in $3.5 \% \mathrm{NaCl}$ solution by using the Mott-Schottky (M-S) analysis technique. The impedance at $0.01 \mathrm{~Hz}$ was used to evaluate the corrosion performance of the coating system as well. Corrosion products formed during the degradation process were detected by X-ray diffraction (XRD) and scanning electron microscopy (SEM). Results showed that the CD of the coating system was approximately $10^{14} \mathrm{~cm}^{-3}$, which was the same as the order of a semiconductor, during the early immersion stage. Subsequently, the CD of the coating system increased with the decrease in $|\mathrm{Z}|_{0.01 \mathrm{~Hz}}$. However, the CD decreased and the low-frequency impedance increased at day 4. This condition differed from the overall tendency and indicated that the corrosion process of the coating system was hindered. The reason could be attributed to the blocking effect of corrosion products $\mathrm{Zn}_{5}\left(\mathrm{CO}_{3}\right)_{2}(\mathrm{OH})_{6}$ and $\mathrm{Zn}_{5}(\mathrm{OH})_{8} \mathrm{Cl}_{2} \cdot \mathrm{H}_{2} \mathrm{O}$, which were generated at the interface of galvanized steel.

Keywords: electrochemical procedure; carrier density; organic coating; semiconductor; coating degradation

\section{$\underline{\text { FULL TEXT }}$}

(C) 2019 The Authors. Published by ESG (www.electrochemsci.org). This article is an open access article distributed under the terms and conditions of the Creative Commons Attribution license (http://creativecommons.org/licenses/by/4.0/). 